\title{
Current Trends and Future Prospects for EU-Turkey Relations: Conditions for a Cooperative Relationship
}

\author{
Wulf Reiners and Ebru Turhan
}

\subsection{INTRODUCTION}

Despite the growing institutional instability and fragility of the relationship, the persisting stalemate in Turkey's EU accession process, and the weakening communication channels between the two sides, EU-Turkey relations have endured. EU-Turkey affairs will remain highly relevant in an age of uncertainty driven by deepening sectoral interdependencies, a growing number of 'intermestic' issues, ${ }^{1}$ and rapid changes in international relations amid processes of geopolitical rebalancing. The EU and

${ }^{\mathrm{l}}$ Intermestic issues 'involve aspects of both international and domestic affairs' (Barilleaux, 1985: 754).

W. Reiners $(\varangle)$

German Development Institute / Deutsches Institut für Entwicklungspolitik (DIE), Bonn, Germany

e-mail: wulf.reiners@die-gdi.de

E. Turhan

Turkish-German University, Istanbul, Turkey

e-mail: turhan@tau.edu.tr

(C) The Author(s) 2021

W. Reiners and E. Turhan (eds.), EU-Turkey Relations, https://doi.org/10.1007/978-3-030-70890-0_16 
Turkey have a shared interest in policy coordination and cooperation that would unlock the potential for mutual gains, negate the externalities of regional or global shocks, and develop reciprocal solutions for joint challenges. Given the relatively short phases of cooperation between the two sides throughout the last decade, what are the conditions under which cooperative trends in EU-Turkey relations could be (re)invigorated?

This volume has mapped and analyzed EU-Turkey relations with a particular focus on developments over the last decade. Our motivation for this systematic reassessment was threefold: (1) to shed light on the current determinants, complexities, and multiplicities of the relationship; (2) to explicate the conditions for a cooperative relationship between the EU and Turkey; and (3) to create a basis for extrapolation into the future trajectory of EU-Turkey relations. This analysis was carried out across three dimensions: theories and concepts, institutions, and policies. The design of this study rested on the assumption that the survey of these interconnected dimensions as distinct objects of investigation offers a multi-angled approach that is fit to examine EU-Turkey relations as a 'moving target'. In this context, the volume has utilized a set of guiding questions related to key turning points and periods, actors and institutional frameworks, policies, and different explanatory and analytical models. This concluding chapter of the volume aims to tie together the lessons from the individual contributions in view of the overarching objectives of the volume and its guiding questions.

Against this backdrop, in the first part of this chapter, we summarize, contrast, and merge key insights derived from this three-dimensional approach to studying the EU-Turkey relationship, offer cross-chapter linkages, and reflect on the different periodizations of the relationship. In a next step, we assess EU-Turkey relations against a set of fundamental, mutually reinforcing enablers of cooperation in order to shed new light on the conditions for a cooperative relationship between the EU and Turkey. Finally, we discuss the future trajectory of EU-Turkey relations and identify avenues for a future research agenda for EU-Turkey studies.

\subsection{TheORIzing AND CONCEPTUALIZING EU-Turkey RELATIONS}

The first part of this volume, 'Theories and Concepts', brought together major conceptual and theoretical approaches to studying European integration and the EU's relationship with third countries. Starting 
from the premise that 'we should be constantly theoretically self-aware, conscious that theoretical perspectives - wittingly or unwittingly-inform our approach to the world that we observe' (Rosamond, 2000: 3), this section offered a comprehensive assessment of EU-Turkey relations and its major milestones through examining both core and up-and-coming approaches. Overall, 'the mosaic of integration theory' (Wiener \& Diez, 2009: 19) is expressed across these contributions, with each theoretical or conceptual approach providing a plausible account for a specific set of key developments. A systematic review of the comparative and complementary readings shows variations and similarities, inter alia, in view of

1. the explanatory factor(s) utilized to explicate the evolution and key turning points of the EU-Turkey relationship,

2. the 'best cases' of the contributions, namely major developments, milestones, and aspects of EU-Turkey relations they plausibly analyze and explain (for a similar description, see Wiener \& Diez, 2009),

3. the diverse readings of the role of EU institutions, and

4. the specific policy areas used in each contribution and how they are seen through the respective theoretical or conceptual lens (see Table 16.1 for a detailed comparison).

Regarding the factors that help explain the EU-Turkey trajectory, the theoretical and conceptual approaches focus on various exogenous, endogenous, and bilateral determinants such as the issue-specific interests of powerful member states and intergovernmental negotiations (liberal intergovernmentalism), values, identities, ethos-driven obligations and self-serving normative argumentations (constructivism, rhetorical entrapment), path dependence and temporality (historical institutionalism), or the EU's normative effects on domestic processes (Europeanization). Conceptual frameworks for studying differentiated integration, which currently occupy the center stage in the scholarly debates on the future of EU-Turkey relations, usually rest on the key premises and explanatory variables as identified in major European integration theories. These factors range from issue-specific interdependence and sectoral spillover effects to ideational consensus (Tekin, Chapter 7). 


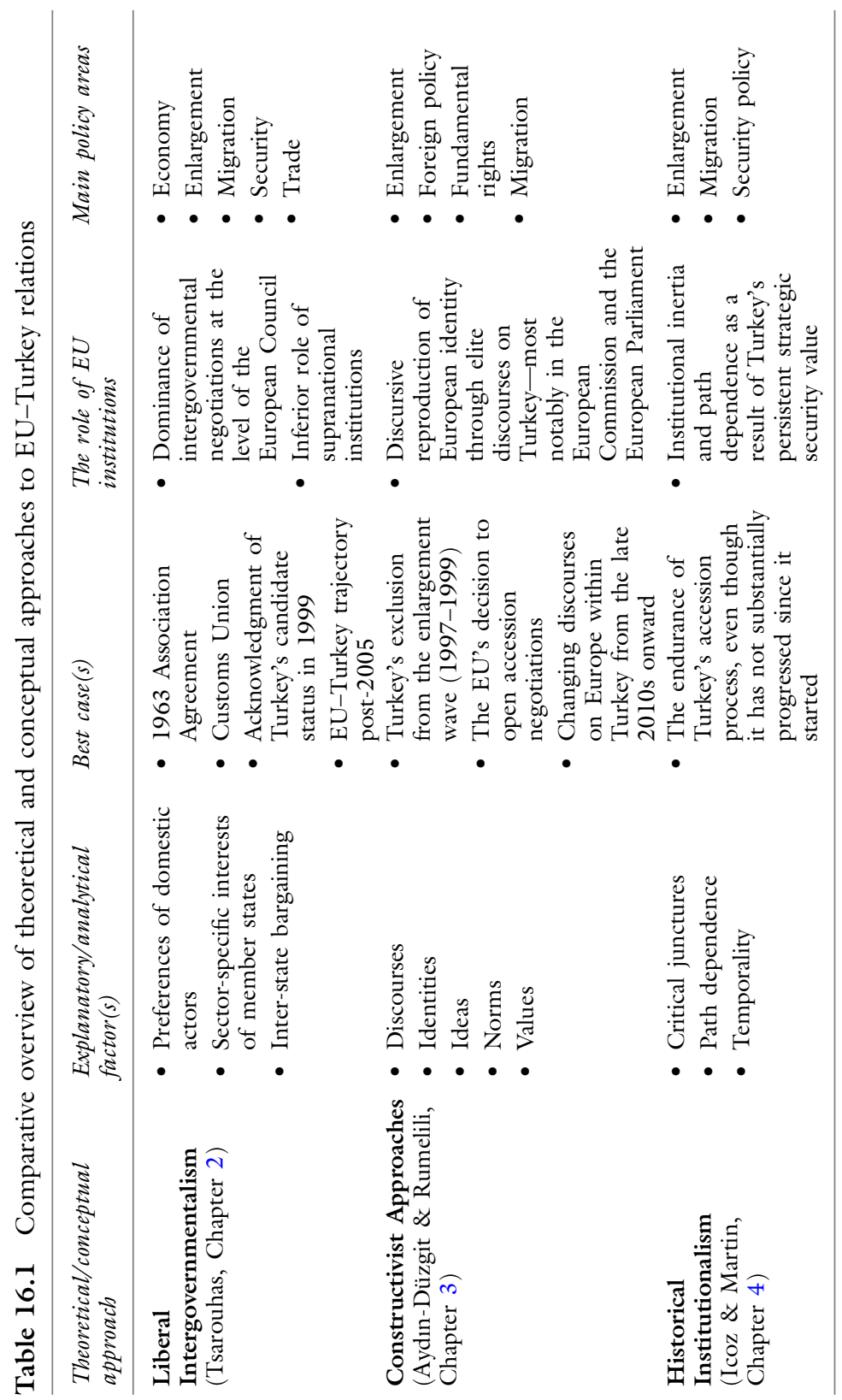




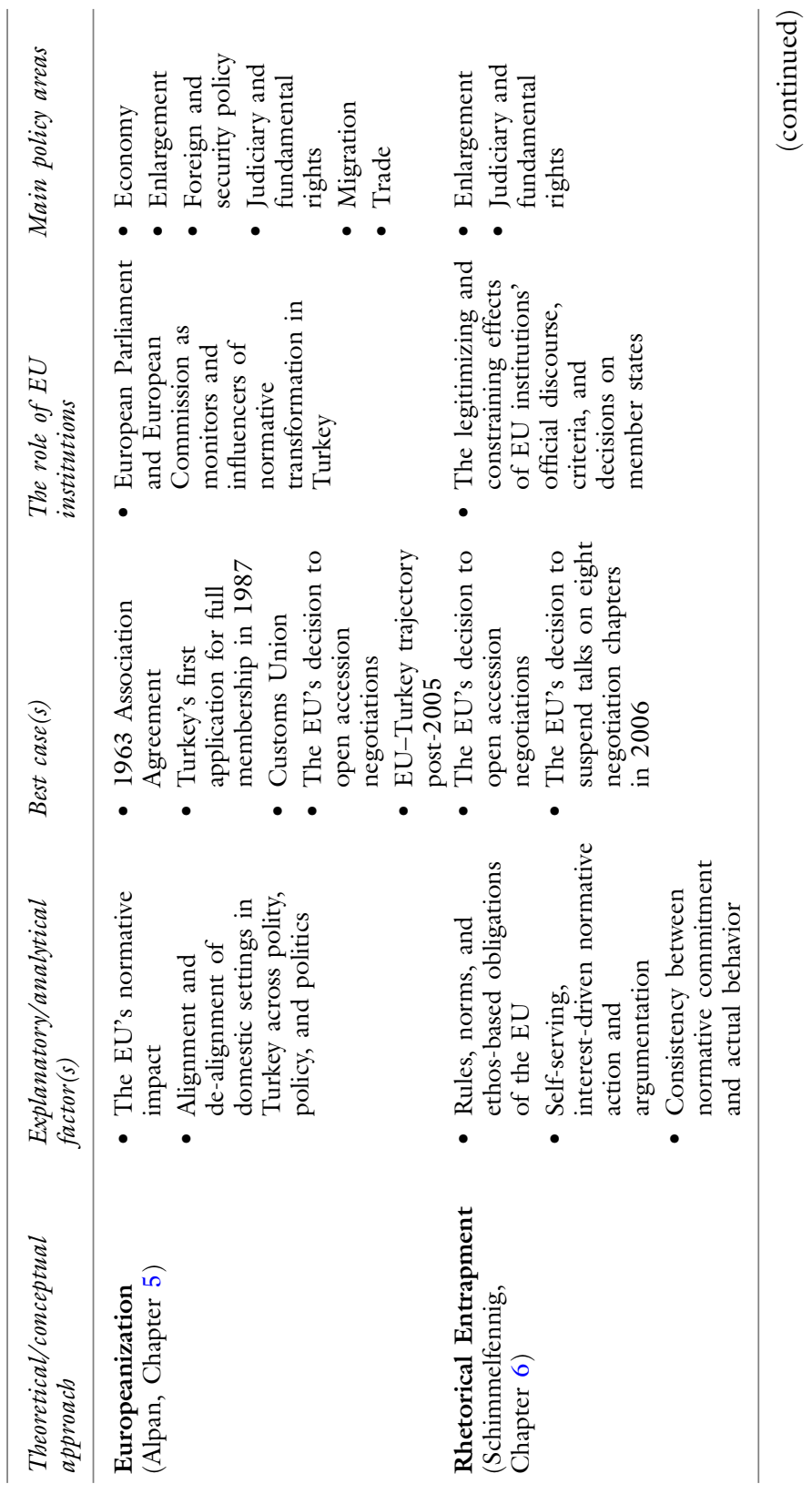




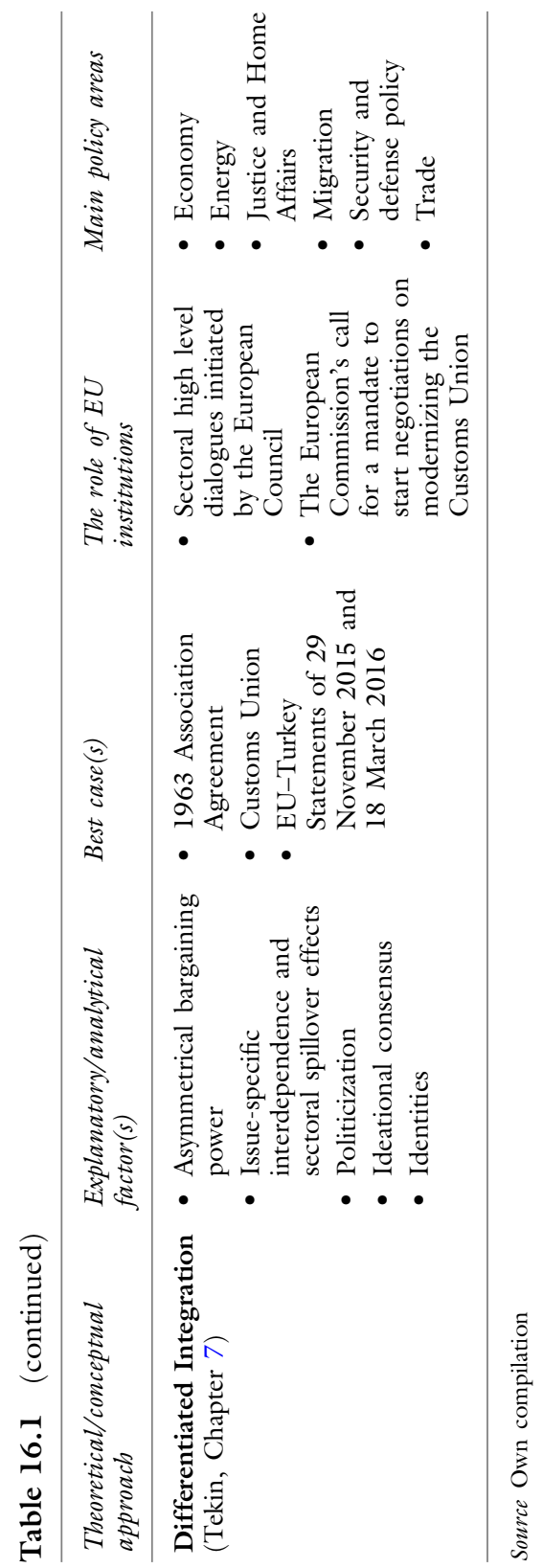


The second point of comparison between the theoretical and conceptual perspectives concerns the strengths and limitations of the main tenets and propositions to conform to 'real-world' patterns. Numerous approaches offer explanations across a wide array of key developments in EU-Turkey relations and competently grasp sector-specific, transactional milestones, such as the signing of the Association Agreement, the establishment of the Customs Union (CU), and the functional trajectory of EU-Turkey affairs post-2005, including the design of the EU-Turkey refugee 'deal' (liberal intergovernmentalism, Europeanization, differentiated integration). Similarly, constructivist approaches and Europeanization provide useful tools to investigate and comprehend different milestones relating to Turkey's accession process. For instance, by falling back on partly overlapping constitutive factors, these approaches elaborate on the set of dynamics that brought about Turkey's first application for full membership in 1987 (Alpan, Chapter 5), its exclusion from the enlargement wave from 1997 to 1999 (Aydın-Düzgit \& Rumelili, Chapter 3), or the EU's decision to open accession negotiations with Turkey (Alpan, Chapter 5; Aydın-Düzgit \& Rumelili, Chapter 3).

The explanatory strength of other approaches lies in their cogent reading of one specific facet of EU-Turkey relations. Whereas historical institutionalism emphasizes the endurance of Turkey's accession process despite limited progress (Icoz \& Martin, Chapter 4), rhetorical entrapment offers explanations for the launch of accession talks in 2005 and their abrupt slowdown by the Council decision in December 2006 (Schimmelfennig, Chapter 6). Overall, the EU's decision to acknowledge Turkey's candidate status in 1999 remains a particular puzzle for almost all approaches. Here, liberal intergovernmentalism provides one of the most plausible accounts of the shifts in the EU's position from 1997 to 1999 by emphasizing large member states' altered preferences (Tsarouhas, Chapter 2; see also Turhan, 2012).

Regarding the role of EU institutions within the theoretical and conceptual foci, the contributions disclose two distinct logics. Liberal intergovernmentalism accentuates the central function of the European Council as an institutional venue where bargaining between member states with variable preferences determines the EU's position on Turkey (Tsarouhas, Chapter 2; see also Turhan \& Wessels, Chapter 8). In turn, the contributions featuring constructivist and historical institutionalist accounts as well as the concepts of Europeanization and rhetorical entrapment stress the role of the EU's supranational institutions. Although 
the approaches address different facets and impacts of the ideational factors under scrutiny, they show convincingly how the European Parliament or the European Commission critically and independently influence EU-Turkey relations through the production and contestation of ideational structures (Alpan, Chapter 5; Schimmelfennig, Chapter 6; see also Bürgin, Chapter 9).

The final point of comparison between the approaches analyzed in this volume is especially pertinent to the policy areas of EU-Turkey relations. When utilizing the analytical framework of their respective approach to the empirical enquiry, most contributors use the enlargement framework as a major point of reference for periods of progress, stagnation, and setbacks. Beyond that, many authors pay attention to a broader set of policy areas including trade and economic policies, migration, energy, judiciary and fundamental rights, as well as foreign, security, and defense policies (see Table 16.1). The fact that the respective analyses (Alpan, Chapter 5; Tekin, Chapter 7) deal with the widest scope of issue areas speaks to the conceptual flexibility of the approaches of Europeanization and differentiated integration. Overall, the policies analyzed in Part I of the volume match the issue areas examined in Part III of the volume, which exhibits their unequivocal relevance for the trajectory of EUTurkey relations as well as displays the dense network of issue-specific interdependencies.

\subsection{The Division of Labor ANd INTERPlay of EU Institutions in EU-Turkey ReLATIONS}

In Part II of this volume, the authors analyzed the functions and preferences of key EU institutions in framing EU-Turkey relations. The contributions show clearly that EU institutions do not operate in a vacuum. Contrarily, they are interlinked with each other, making interinstitutional cooperation a necessity for the EU's institutional machinery to function effectively in its relationship with Turkey. For example, the European Council is neither able to make far-reaching, positive decisions on Turkey's accession process like the opening or finalizing of accession talks nor can the EP vote on a visa-free travel regime for Turkish citizens without a conclusive recommendation from the Commission. The institutional dimension of EU-Turkey relations is not static. The functions and influence of EU institutions are contingent upon both the dynamic design of the EU's institutional architecture as well as on the fluctuating 
salience and prominence of key components of the relationship, which are being continuously reshaped by endogenous, exogenous, or bilateral developments. For instance, the European Council became a key player in Turkey's accession process from 1997 onward, while its central role as a collaborator with Turkey in managing external shocks became palpable after the onset of the so-called 'refugee crisis' in 2015 (Turhan \& Wessels, Chapter 8). In turn, despite its pivotal role in the implementation of the refugee 'deal', the Commission is mainly responsible for closely managing the technical aspects of the institutionalized enlargement framework. The stagnation of Turkey's accession process has therefore translated into a partial loss of the Commission's power to actively shape the relationship.

Even though the institutional balance of the EU-Turkey relationship is subject to constant recalibration, this volume reveals two salient trends among EU institutions. First, there is a consistent division of labor among the three EU institutions under scrutiny. The European Council is at the heart of the EU's institutional machinery maintaining relations with Turkey. It develops the relationship through employing its capacity to make monumental, far-reaching, and path-setting decisions, including the institutionalization of the bilateral relationship. The initiation of bilateral summits and the establishment of high level dialogues are examples of the European Council's role in setting relations. The European Council is strongly interested in carving a strategic relationship model that could utilize Turkey's potential as a regional security-enabler that would offset the externalities of regional or international crises (Turhan \& Wessels, Chapter 8). Accordingly, the Heads of State or Government strive to act as an overarching 'stabilizer' of EU-Turkey relations in times of acute political tensions between Turkey and the EU or its member states. The fact that the European Council endorsed the 'conditional' launch of a 'positive political EU-Turkey agenda' in the event of Turkey's constructive dialogue with Greece and Cyprus on the Eastern Mediterranean crisis and the territorial disputes (European Council, 2020: para. 19) showcases its interest in maintaining a functional, interest-driven relationship. Contrarily, the Parliament and the Commission evaluate EU-Turkey relations predominantly from a normative point of view, placing a particular emphasis on democracy, human rights, fundamental freedoms, and the rule of law (Bürgin, Chapter 9; Kaeding \& Schenuit, Chapter 10). As Bürgin points 
out, given its role as the manager of the EU's Instrument for PreAccession (IPA) funding for Turkey, the Commission remains an influential 'agent of change' via institution building and social learning, even in times of conflict, through the largely horizontal and transgovernmental cooperation frameworks it has maintained with Turkish authorities.

As a second overarching trend we observe that all EU institutions under scrutiny have progressively distanced themselves from Turkey's EU accession prospects on the grounds of partly overlapping and partly exclusive considerations. The Commission has long acted as a 'critical but fair supporter of Turkey's accession' (Bürgin, Chapter 9), even when faced with opposition from individual member states that seek to weaken Turkey's membership perspective. However, following the normative concerns expressed in its regular country reports, it no longer blatantly advocates for Turkey's membership. The European Council has left the criticism of Turkey's normative distance from the EU mostly to other institutions, particularly after the launch of the accession negotiations in 2005. Still, the contribution by Turhan and Wessels (Chapter 8) contains plenty of proof that the 'accession narrative' has also gradually disappeared from the agenda of the Heads of State or Government. Regardless of their overarching, unequivocal 'Turkey-fatigue', commitment to the preservation of Turkey's accession process prevails in the official discourses of both institutions. Contrarily, as the EU's primary 'normative voice' (Feliu \& Serra, 2015), the Parliament seems to have officially 'closed its accession door for Turkey' following its successive calls to suspend accession negotiations and has made severe adjustments to its voting behavior on Turkey-related files since 2005 (Kaeding \& Schenuit, Chapter 10).

\subsection{The Role of Policies in EU-Turkey Relations Inside AND OUtSIDE THE ACCESSION FramewOrK}

The contributions in Part III of this volume examined the interactions between the parties inside and outside the accession context that influence the most critical policy areas. The studies reveal, inter alia, the partly paradoxical presence of both complexity and longevity in the EUTurkey relationship. In all areas under scrutiny-enlargement policy, trade and macroeconomic policies, foreign and security policy, migration and asylum policies, and energy policy-we can observe the puzzling existence of both fortified sectoral interdependencies, on the one hand, and increasingly diverging normative and material preferences, on the other. 
Accordingly, the respective contributions bring us full circle to the starting point of this volume: examining the new complexities of EU-Turkey relations.

The EU's enlargement policy is the most important reference point for the development of the EU's relationship with candidate countries across manifold policy areas. It induces a hierarchical type of external governance through imposing conditionality, which promotes the extraterritorial expansion of the EU acquis to third countries. The principle of conditionality means that the candidate country's adoption of EU norms in respective policy areas usually facilitates and expedites the accession process. At the same time, a stalemate in accession negotiations can come with setbacks in policy transfer and convergence. This is particularly true for policy areas dominated by the strong asymmetry of interests in favor of candidate countries, on the one hand, and absent or weak EU incentives outside the accession scheme, on the other (Lavenex and Wichmann, 2009; Turhan \& Ylldiz, forthcoming). Thus, the configuration of the enlargement framework yields implications for basically all policies-for better or worse.

In this context, in Chapter 11 Lippert examines how considerations of Turkey's 'Europeanness' (see also Aydın-Düzgit \& Rumelili, Chapter 3; Alpan, Chapter 5), its strategic position (as either an asset or a burden), and its conceivable impact on the Union as a full member have shaped the EU's enlargement policy vis-à-vis Turkey. Accordingly, the EU has addressed Turkey with exceptionally ambiguous accession prospects since its initial application for membership in 1987 and throughout the accession negotiations. The overarching opacity and eccentricity of the EU's enlargement policy have been echoed in the special provisions of Turkey's negotiation framework and the vetoes of single member states against the opening of critical negotiation chapters (see also Turhan \& Wessels, Chapter 8).

The contributions dealing with thematic policy issues disclose the repercussions of the EU's ambiguous-and somewhat normatively incon-

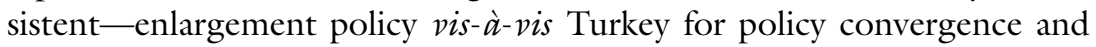
harmonization. In all domains under scrutiny, the acknowledgment of Turkey's candidacy and the launch of accession negotiations have engendered attractive external incentives that have facilitated Turkey's adoption of EU norms. The weakening of the EU's accession conditionality from 2007 onward as a result of individual member states' unilateral vetoes has interfered with Turkey's further alignment with 
the EU acquis. Additional factors beyond the accession context have contributed to Turkey's alienation from EU norms as well. These have ranged from exogenous determinants like the 2008 global financial crisis and the gradual shift of the economic center of gravity toward Asia (Akman \& Çekin, Chapter 12) to the war in Syria and mounting pressure from mass migration (Kaya, Chapter 14) as well as changing regional dynamics following the Arab uprisings (Torun, Chapter 13). Endogenous determinants like the de-secularization of Turkey's foreign and domestic policymaking (Kaya, Chapter 14), its dwindling democratic credentials (Lippert, Chapter 11), and bilateral developments including the EU's suspension of all sectoral high level dialogues in July 2019 (see, e.g., Sartori, Chapter 15) have added to the estrangement.

Today, the EU's role as an anchor and its normative model facilitated by the accession conditionality are no longer considered an 'elixir' for Turkey's domestic transformation (Akman \& Çekin, Chapter 12). Still, the contributions of Part III of the volume reveal two key features that need to be taken into account when conjecturing about the future trajectory of the bilateral relationship. First, the findings emphasize the need for continued cooperation between the EU and Turkey across a wide spectrum of issue areas. A cooperative relationship is key to negating external shocks and power shifts in the respective domestic contexts and augmenting mutual gains. Second, the comparative analyses of the policy areas disclose that EU-Turkey relations are likely to take place along a transactional, sector-driven axis largely decoupled from Turkey's EU accession process, at least in the foreseeable future. Accordingly, policy convergence will be more likely to occur through ad hoc provisional mechanisms (Torun, Chapter 13) and bottom-up technical and operational cooperation (Sartori, Chapter 15) that is less prone to politicization (see also Tekin, Chapter 7).

\subsection{Competing AND Converging Periodizations of EU-Turkey Relations}

The history of EU-Turkey relations is not linear. Analyses of EU-Turkey relations from theoretical, institutional, and policy perspectives organize these developments into various periods according to the respective approach, institution, or policy field under scrutiny. Periodizations are a useful tool to understand EU-Turkey relations as they help 'partition the stream of events in such a way that important developments 
become visible' (Zürcher, 2004: 1). The cornerstones within this 'stream of events' according to most perspectives are, inter alia, the 1963 Association Agreement, the start of accession talks in 2005, and the 'refugee crisis' starting in 2015. It is beyond the scope of our analysis to assess in detail the quality of cooperation among the EU and Turkey within particular periods of time. However, locating the relationship on a continuum between cooperation and confrontation can show how policies developed both independently and together. In this context, elements that show increasing Europeanization in Turkey or policy convergence and alignment between the two sides fall along the cooperation side of the continuum, whereas policy divergence or de-Europeanization trends in Turkey run closer to the confrontation side.

Most scholars agree that the period subsequent to the December 1999 European Council meeting, where Turkey was granted the status of EU candidate, can be considered the 'golden era' of the relationship. This resulted from the combination of a favorable constellation of internal EU actors (e.g., domestic political landscape in key member states), external influences (e.g., the EU's security considerations after the Kosovo war), and vigorous transformation processes across various issue areas on Turkey's end. However, alternative viewpoints exist on when this most cooperative phase of the relationship came to an end. Whereas some scholars (Tsarouhas, Chapter 2; Icoz \& Martin, Chapter 4; Lippert, Chapter 11) stress the emergence of difficulties in Turkey's accession talks and the alignment with EU norms from 2005 onward, other analysts observe the perseverance of a rather cooperative period up until the global financial crisis in 2008 (Akman \& Çekin, Chapter 12). If constructivist contributions to the field of EU-Turkey relations are taken as the reference point, the 'period of convergence' holds up until 2011 (Aydın-Düzgit \& Rumelili, Chapter 3).

There is an agreement, however, that the period of palpably diverging paths for the EU and Turkey started sometime between 2010 and 2012. To illustrate, Turkey's constitutional changes in 2010 and other domestic developments have been identified as the starting point of deEuropeanization (Alpan, Chapter 5). From the Parliament's perspective, decreasing support for Turkey's EU membership can be observed in the period beginning in 2012 (Kaeding \& Schenuit, Chapter 10). Looking at international events, the changing political and societal landscape in the Middle East in 2010/2011 amid the Arab Spring can be marked as the end of the Justice and Development Party's (Adalet ve Kalkınma Partisi, 
AKP) policy of 'zero-problems with neighbors'. It also marks the point of departure and increased divergence between the EU and Turkey over Syria (Torun, Chapter 13).

\subsection{The Future of EU-Turkey Relations: The Conditions For AN (UN)COOPERATIVE RELATIONSHiP}

The findings of the individual chapters of this volume highlight three interconnected features of contemporary EU-Turkey relations: first, the bilateral relationship is driven by the paradoxical coexistence of increasing interdependencies and the growing divergence of normative and material preferences. Second, as a result of this puzzling equilibrium, EU-Turkey relations do not exhibit a clear, linear developmental path characterized by cooperative action. The contributions provide evidence that cooperation has to some degree been replaced by competition and confrontation, particularly throughout the last decade. Third, there is a growing trend toward the sustenance and study of the relationship outside the accession context. When bilateral cooperation becomes constrained or impossible despite growing issue-specific interdependencies, how will the EU and Turkey possibly overcome the impasse outside the accession framework? Against this background, the following sections examine the conditions for a future (un)cooperative relationship between the EU and Turkey taking into account the new complexities that epitomize the bilateral dialogue.

In order to decipher the conditions under which cooperative trends in EU-Turkey relations could be reinvigorated, we should explicate what we understand by 'cooperation'. A standard definition of the term in International Relations (IR) describes it as the phenomenon 'when actors adjust their behavior to the actual or anticipated preferences of others, through a process of policy coordination' (Keohane, 1984: 51). Within this context, the concept of 'policy coordination' means that the policies of the actors involved are designed in a way so that they reduce the negative consequences for the cooperating partners (Milner, 1992). Other understandings of cooperation entail 'collective action applied to the particular circumstances of the international system' (Snidal, 1985: 923) that involves 'either (1) bargaining over the division of new or potential benefits; or (2) attempts to renegotiate an existing cooperative arrangement, where one party threatens to revert to noncooperation if the present terms are not adjusted' (Fearon, 1998: 275). 
We take up the basic features of the aforementioned definitions in order to compose our definition of a 'cooperative relationship'. 'Relationship' in this context implies a certain degree of stability, including the existence of infrastructures and tools that facilitate long-term cooperation processes. We do not limit our interest to the conditions under which the EU or Turkey would 'give up something, or give up more, than the other party' as part of the cooperation process (Messner et al., 2016: 49). Our interest also extends to those instances when the EU and Turkey communicate, coordinate, or collaborate in order to achieve their (common or individual) goals and acquire mutual gains (Milner, 1992) in looser (negotiated) yet reasonably stable frameworks. In this context, we build our analysis on a set of principles that tackles the 'behavioral dimension' of cooperation (Messner \& Weinlich, 2016). More precisely, we consider an environment that stimulates cooperation between the EU and Turkey to be characterized by the positive repercussions of seven mutually reinforcing enablers: reciprocity, trust, communication, reputation, fairness, enforcement, and common identity (Messner et al., 2016).

\subsubsection{High Potential for 'Reciprocity' Beyond the Accession Context}

'Reciprocity' constitutes the key enabler of cooperation (Messner et al., 2016). It concerns mutually beneficial 'exchanges of roughly equivalent values in which the actions of each party are contingent on the prior actions of the others in such a way that good is returned for good' (Keohane, 1986: 8). Thus, in the context of EU-Turkey relations, reciprocity refers to situations where the EU or Turkey do something for their counterpart in return for something they receive. With a view to the future traits of the relationship, the assessment of reciprocity is crucial in particular in the enlargement context, as well as in migration, trade, security, and energy policies.

With regard to the former, the accession process is no longer perceived as a reciprocal setup. At the turn of the millennium, the Commission and Parliament, as well as member states like the United Kingdom (UK), had a clearer idea of the reciprocal potential of Turkey's membership (Turhan, 2012; Bürgin, Chapter 9; Kaeding \& Schenuit, Chapter 10), and only few member states like France or Cyprus emerged as key skeptics. Today, membership-related reciprocity is no longer a dominant narrative in any member state or EU institution (Lippert, Chapter 11; Turhan \& Wessels, Chapter 8). Given Turkey's geo-strategically compelling location and its 
direct involvement in conflicts in its unstable neighborhood, the EU's calculus features a perspective on Turkey as rather a 'barrier' than a 'bridge' (Park, 2007: 159). Even if the path dependent nature of Turkey's EU accession process endured due to Turkey's potential as a security provider (see Icoz \& Martin, Chapter 4), the growing turn toward an illiberal course in various 'new' member states that acceded the EU during the Eastern enlargement as well as 'enlargement fatigue' make it difficult on the EU's end to envision the gains of Turkey's full accession. Similarly, Turkey's perspective has changed, too, as it-after a period of rapid convergence (see periodizations, above)—no longer seems to be devoted to implementing a political transformation in line with the Copenhagen criteria, to 'Europeanize', and ultimately, to fully adopt the acquis in return for increased prospects to 'gain' membership in the long run. This shift away from the membership perspective, however, is not clearly articulated in Turkey's official political discourse; membership continues to constitute rhetorically the only desired and feasible scenario for Ankara.

At the same time, the volume provides plentiful evidence that the potential for reciprocity in EU-Turkey relations is seemingly greater than ever given the entanglement of both parties in a growing network of interdependence. Migration is a key policy field in this regard, in particular since the two sides developed reciprocal ties during the 'refugee crisis' in 2015 and 2016 (see Turhan \& Wessels, Chapter 8; Kaya, Chapter 14). The EU-Turkey arrangement to address irregular migration is a prime example of direct reciprocity. Despite the uncertainties regarding the continued implementation of the refugee 'deal', the cross-border nature of this issue-area and the asymmetrical interdependence in favor of Turkey (Turhan \& Yıldız, forthcoming) require some form of institutionalized cooperation between the EU and Turkey. The (re-)configuration of this reciprocal setup in migration and asylum affairs, however, will also depend on the 'process to take stock of the implementation of the EU-Turkey Statement' (European Commission, 2020a: 3-4) following Ankara's call for a new 'deal', as well as on the future shape of the EU's asylum and migration system. The EU's response to the catastrophic conditions of refugees and asylum seekers in its frontline member states will not only define how far the EU is able to live up to its proclaimed norms and values, but it will also define its dependency on Turkey and the extent of Turkey's leverage regarding the conditions of cooperation. 
Regarding trade, the EU-Turkey Customs Union (CU) is still perceived as an institutional arrangement that allows for mutual reciprocity, despite growing concerns on the Turkish side over its asymmetric setup. However, even if the CU constitutes one of the remaining functioning pillars of EU-Turkey relations, analysts stress the necessity for its modernization in order to overcome its outdated form, unlock the potential for greater mutual economic benefits, and reinforce political ties between the two sides through Turkey's participation in regulatory decision-making. In this way, the modernization could also consolidate the institutional dimension of the trade relationship with potential for spillover effects in other policy areas (Akman \& Çekin, Chapter 12; Tekin, Chapter 7). More immanently, the EU's emergent relationship with the UK will serve as a reference point in the discussions on EUTurkey trade relations and the future trajectory of the CU. The European Council's endorsement of the 'conditional' launch of a 'positive political EU-Turkey agenda with a specific emphasis on the modernization of the Customs Union and trade facilitation' in return for Turkey's cooperative behavior regarding the Eastern Mediterranean crisis (European Council, 2020: para. 19) demonstrates high potential for reciprocal solutions at the intersection of trade, energy, and security interests.

In the security dimension, the EU and Turkey face strong interdependencies in the field of counterterrorism and in the Middle East, not least in pursuit of addressing 'the causes of flight from Syria and beyond' (Kaya, Chapter 14). Despite a presumed shared vision of regional stability, security, and prosperity along each party's respective borders (European Commission, 2018; İletişim Başkanlığ 1 2019) and the high potential for reciprocal benefits stemming from cooperation, neither side is currently ready to adjust its policies in accordance with the strategic preferences of the other side. Turkey's considerably unilateral foreign and security policy in the Middle East is guided by its neo-Ottoman ambitions (Kaya, Chapter 14), and its distinct security interests along its borders take advantage of the power vacuum in the region. At the same time, the EU faces internal problems in translating its traditional championing of multilateralism into action in the face of unilateral responses from individual member states independent of concerted action. The EU and Turkey face severe incompatibilities in formulating common policy objectives regarding the maritime borders in the Eastern Mediterranean and the Aegean Sea as well as the Libyan civil war (Torun, Chapter 13). Still, building on institutionalized security cooperation between the EU 
and Turkey within the North Atlantic Treaty Organization (NATO) and beyond, a reassessment of the reciprocity dimension of cooperation might take place considering endogenous and exogenous factors. These factors range from increasing conflict-related costs (not only of warfare but also related to migration and public opinion; see Kaya, Chapter 14) to discontent with a third power's assertive foreign policy (e.g., Russia) or power struggles in the region (e.g., between Turkey and Egypt). Given that 'Turkey [is] increasingly isolated on the global stage' (EIU, 2020: 26), foreign policy cooperation with the EU might become more attractive again.

Finally, in the energy domain, it is important to highlight the relevance of the new 'green consensus' in the EU, which will also be the primary reference point for the EU's evaluation of reciprocity in its energy relations with Turkey (see Sartori, Chapter 15). In the future, the debates over EU-Turkey energy cooperation will have to consider the development of Europe's new Leitbild as a climate-neutral continent. This new narrative is most prominently reflected in the 'European Green Deal' (European Commission, 2019a), which simultaneously steers the EU's growth strategy and response to the COVID-19 pandemic. The EU has already made clear that the Green Deal is the main reference point for its prospective global role, which it will address through external action instruments including diplomacy, trade, and development cooperation (European Commission, 2019b). Hence, alongside disputes over gas exploration and exploitation in the Eastern Mediterranean, the assessment of reciprocity in EU-Turkey energy relations will depend on Turkey's willingness and ability to develop a 'green agenda' that responds to the EU's re-orientation toward climate protection and the EU's aspired future green development model.

\subsubsection{The Absence of 'Trust' in EU-Turkey Relations}

'Trust' constitutes a second important enabler of cooperation. The term can be defined as 'an expectation of cooperation and reciprocity' (Rathbun, 2011: 3) despite a lack of total certainty. Whereas mistrust would constitute the 'belief that the other side prefers exploiting one's cooperation to returning it' (Kydd, 2007: 6), trust between the EU and Turkey implies that actors on both sides are confident that interaction will eventually result in reciprocity and will not harm the respective interests of any party. 
The issue of trust is not a new topic in EU-Turkey affairs. In the field of foreign and security policy, scholars have asserted 'a historical and instinctive mistrust of European diplomacy in Ankara that dates back to the Ottoman times' (Park, 2007: 160). However, in contemporary EU-Turkey relations, trust seems to be absent to a large extent on both sides in interactions in almost all critical policy fields. It must therefore rather be understood as a fundamental cause for uncooperative behavior between the EU and Turkey fed by mutual resentments. Throughout the last few years, trust between both parties has hit historic lows, as illustrated by the characterization of the relationship as 'beset with mistrust, frustration, disillusionment and disappointment' (Yenel ${ }^{2}$ quoted in Euronews, 2015). Surveys show that tensions and mistrust at the political level also trickle down to the public domain both in the EU and Turkey. In a public opinion poll conducted in Germany in 2018, $92 \%$ of respondents stated that Turkey could not be considered as a trustworthy partner for Germany when it comes to political cooperation (Forschungsgruppe Wahlen, 2018). Similarly, the Eurobarometer results show that as of Autumn 2019, only 33\% of Turkish citizens trusted the EU, whereas 60\% did not (European Commission, 2019c).

In the EU, Turkey's progressive backsliding in its alignment with EU norms plays a significant role in the development of expectations about the behavior of Turkey's political leadership. However, the effects of the domestic transformation on cooperation with the EU at the technical level have not yet been fully understood (Bürgin, Chapter 9). The instrumentalization of Syrians residing in Turkey and the readmission component of the EU-Turkey 'deal' as a bargaining chip by the Turkish side (Kaya, Chapter 14) also feed into the EU's disbelief in Turkey's intention to return rather than exploit the opportunities for cooperation. On the Turkish side, an obvious source of mistrust is the long-lasting ambiguity regarding Turkey's accession prospects fueled by the exclusionary rhetoric of European leaders toward Turkey (Aydın-Düzgit \& Rumelili, Chapter 3) and individual member states' blocking of chapters in the accession negotiations (Turhan \& Wessels, Chapter 8). At the same time, democratic movements and opposition

\footnotetext{
${ }^{2}$ Ambassador and permanent delegate of Turkey to the European Union from 2011 to 2017.
} 
forces in Turkey are disenchanted with the EU's (missing or ineffective) response to the erosion of rule of law and human rights in Turkey (Şenyuva, 2018).

Given the difficulties in the overarching macro-institutional framework of Turkey's stalled accession process and increasing political tensions between the highest political representatives from the EU and Turkey, mutual trust needs to be built up again to overcome the obstacles to a future cooperative relationship. In this context, multi-level socialization processes based on transgovernmental networking can serve as an important tool. Transgovernmental, horizontal networks facilitate 'bottom-up, inclusive and voluntary modes of interaction' (Lavenex \& Wichmann, 2009: 99) between multi-level actors, including regulatory agencies, local administrators, non-state actors, and technocrats (Lavenex, $2008,2014)$. The prospective launch of a 'positive political EU-Turkey agenda' as mentioned in the European Council conclusions of 1 October 2020 envisages enhanced people-to-people contacts (European Council, 2020) - a step that might promote the establishment of a mutual trust environment through transgovernmental networking.

\subsubsection{A Sophisticated but Largely Deactivated 'Communication' Infrastructure}

'Communication' is considered another important enabler of cooperation due to its fundamental impact on mutual trust by reinforcing actors' ability to assess the other's expectations, to develop joint understandings and plans, and to assure each other about intended activities (Messner et al., 2016). In EU-Turkey relations, communication, rhetorical structures, and discourses have proved to be simultaneously influential and complex (see Schimmelfennig, Chapter 6; Aydın-Düzgit \& Rumelili, Chapter 3). The EU and Turkey developed an unparalleled system of exchange that goes far beyond a regular framework of accession negotiations. It includes, among others, the EU-Turkey Joint Parliamentary Committee, the EU-Turkey Association Council, the joint summits, and various sector-specific high level dialogue mechanisms (see Turhan \& Reiners, Chapter 1). That almost all of these critical channels have been deactivated or significantly downsized since 2019 essentially degrades the bilateral communication infrastructure to an ordinary setup that does not correspond to the complex and multilayered cosmos of EU-Turkey relations. When ad hoc meetings between presidents of key EU institutions 
or the High Representative and Turkey's president or foreign minister serve as the primary format for exchange, opportunities-and time-to create mutual understandings of common challenges and to develop joint solutions remain limited.

Membership in multilateral organizations and forums such as the G20, the Organization for Security and Cooperation in Europe, the Council of Europe, or NATO provide additional communication channels. However, they can hardly be seen as sophisticated alternatives to the complex bilateral communication infrastructure between the EU and Turkey given their broad thematic and geographic scope, the heterogenous capabilities and preferences of their member states, and the internal problems of these organizations. In times of regional power struggles and rivalries between the EU and Turkey — as in the case of the Eastern Mediterranean-NATO may even emerge as an additional trouble spot rather than a platform for trust-enabling communication. Such developments generate the paradoxical situation in which the EU and Turkey in principle have more elaborate communication tools at their disposal than most other international relationships do. At the same time, direct and systematized communication between both sides at the political level is weak, with the EU and Turkey remaining compelled to once again 'create the much-needed space for dialogue' (European Commission, 2020b: 18).

In this context, however, differentiation between communication at the political and the administrative levels is imperative. On the one hand, we find an increasing reluctance to opt for a diplomatic tone by key political actors on both sides and a shift in the mode of interaction 'from arguing to bargaining, from the use of values and norms to the exchange of threats and promises' (Schimmelfennig, Chapter 6). On the other hand, as Bürgin points out in Chapter 9, at the more technical, operational level, communication and cooperation might remain to some degree decoupled from the broader political context. Thus, transgovernmental communication structures with technocratic and functional features could promote a horizontal cooperative relationship. The reactivation of suspended sectoral high level dialogue mechanisms could further facilitate the normalization of EU-Turkey communication.

\subsubsection{The Vicious Circle of Ruined 'Reputation'}

'Reputation' is an enabler-or inhibiter-of cooperation that takes into account the EU's and Turkey's evaluations of the other side's behavior 
in the past in view of its possible future actions (Messner et al., 2016). Reputation is subject to constant reproduction as experiences of past and new performances continuously provide an updated assessment of the perceived trustworthiness of the cooperation partner(s). At the same time, it is the result of experiences over a longer period of time. Contemporary EU-Turkey relations can hardly build on this mechanism to facilitate cooperation between both parties. Changed perceptions of reciprocity, the lack of mutual trust, and sentiments about unfair/inconsistent decisions and treatment by the other party (see below) have paved the way to a vicious circle where both the EU and Turkey continually question the reputation of the respective side's key actors and institutions. A ruined reputation imperils cooperation as it inhibits actors from adjusting their policies to the actual or anticipated preferences of others.

The EU's reputation in Turkey is embedded in the long-established mistrust over the EU's sincerity concerning Turkey's accession process and prospects. The deflated credibility of EU conditionality-which remains contingent on 'the consistency of an organization's [here: the EU's] allocation of rewards' (Schimmelfennig \& Sedelmeier, 2004: 666) - and individual member states' vetoes over critical negotiation chapters have mitigated the EU's reputation in Turkey. From the perspective of the Turkish political elite, the EU's perception as a reputable cooperation partner was further impaired by shortcomings in the expeditious delivery of incentives as stipulated in the March 2016 EU-Turkey Statement.

Turkey's reputation in the EU, on the other hand, has been largely constructed in consideration of Turkey's illiberal drift throughout the last decade, which has weakened its alignment with EU norms and, consequently, the formulation of a reciprocal relationship under the auspices of the enlargement scheme. In recent years, Turkey's increasingly interventionist and independent foreign policy approach toward its immediate neighborhood (see Torun, Chapter 13) coupled with its occasional instrumentalization of refugees in order to reach its foreign and economic policy goals (see Kaya, Chapter 14) have served as additional drivers of its problematic reputation.

In order for both the EU's and Turkey's reputation to play a positive role in enabling a cooperative relationship in the future, both actors will have to adjust their activities in stronger consideration of the preferences of the other side over a longer period of time. Some starting points for this process could be the EU's return to attractive and credible incentives 
for Turkey inside and outside the accession scheme. On Turkey's end, increased alignment with Chapters 23 and 24 of the acquis and a recalibration of its foreign policy in pursuit of multilateral instruments could help mend its weakened reputation within EU circles.

\subsubsection{Diverging Conceptions of 'Fairness'}

'Fairness' is a factor that can further increase the likelihood, quality, and stability of cooperation (Messner et al., 2016). In a cooperative arrangement, the principle of fairness engenders certain rights and obligations for the respective parties. While the rights concern 'the cooperating parties' entitlement to a practice that satisfies the general principle of reciprocity', obligations refer to 'their expectation of compliance from other participants in and beneficiaries of the practice' (Kokaz, 2005: 69). Accordingly, fairness plays a significant role in participants' 'adoption of other-regarding preferences [that] may be crucial to the establishment of cooperative arrangements-arrangements that are deemed by all parties to be of mutual advantage' (Kapstein, 2008: 236).

The principle of fairness has long been a key component of Turkey's official discourse on EU-Turkey relations. Turkey's portrayal as an 'honourable but victimized side of the relationship; a party that has exerted itself to the utmost and kept all of its promises and yet been subjected to an unfair, disrespectable, and deceptive treatment by the EU' (Hauge et al., 2019: 28) has often remained at the core of successive Turkish governments' readings of the relationship. The analysis of Turkey's accession history has made clear that the decision to not include Turkey in the major enlargement rounds of 2004 and 2007 was perceived as an unfair exclusion on the Turkish end together with the unilateral, arbitrary vetoes of individual member states of the opening of accession talks in critical chapters of the acquis (Turhan \& Wessels, Chapter 8; Lippert, Chapter 11). From the Turkish perspective, unfairness also exists in EU-Turkey relations outside the accession framework. It prevails within the asymmetric design of the CU (Akman \& Çekin, Chapter 12), the benchmarks for visa liberalization, and responsibility and burden-sharing related to the management of the Syrian refugee crisis (see, e.g., Barigazzi, 2016). The Eastern Mediterranean gas dispute, in 
which Turkey's territorial claims conflict with Greek and Cypriot interpretations of international law, is another example in which Turkey has called on the EU to 'be fair' (Oktay ${ }^{3}$ quoted in Zeit Online, 2020).

Whereas Turkey's current perception of EU-Turkey relations largely centers on the concept of 'unfairness', for the EU, fairness in EU-Turkey relations is first and foremost addressed through the official accession criteria, which are valid for all candidates. In a similar vein, the EU refers to fairness in the context of transparent benchmarks that measure Turkey's compliance with pre-determined, non-negotiable EU norms, which become effective in conditionality-driven processes such as the Visa Liberalization Dialogue.

In order to make fairness a facilitator of a cooperative relationship in the future, it is important that both sides understand that the assessment criteria for what is considered fair might be subjective and vary depending on different cultural and societal settings (Schäfer et al., 2015). Leading representatives' ability to arrive at this understanding necessitates an intensification of communication that respects the specific cross-cultural and domestic setup of EU-Turkey relations.

Alongside a better understanding of, and respect for, the key determinants of fairness as perceived by the respective other side, fairness in EU-Turkey relations could also be reinforced by the EU's and Turkey's proper exercise of their roles and responsibilities. In this respect, Turkey could, for example, make greater effort to reverse the de-Europeanization process if it wants to be seen as a determined accession candidate. The $\mathrm{EU}$, on the other hand, could start by addressing the refugee crisis in a way that goes beyond an externalization strategy shifting central responsibilities to Turkey.

\subsection{6 'Enforcement' Without Accession Incentives}

Research on cooperation has shown that certain means of 'enforcement' can serve as promoters of cooperation when rewards or punishments are in place to incentivize compliance with jointly established or unilaterally determined norms and condemn misbehavior (Messner et al., 2016). In EU-Turkey relations, the accession conditionality used to be the primary apparatus to incentivize cooperation and hierarchical

${ }^{3}$ Vice president of Turkey since July 2018. 
policy transfer, particularly from 1999 to 2006, until Turkey's accession prospects started to weaken (see Alpan, Chapter 5). The IPA funds still serve to a limited degree as a driver of Turkey's sectoral alignment with the EU acquis, not least by promoting social learning processes between European and Turkish technocrats (Bürgin, Chapter 9). However, these funds can neither singlehandedly engender the extraterritorial promotion of EU norms and rules in Turkey nor safeguard the longevity of EU-Turkey cooperation.

For that reason, instruments of enforcement in EU-Turkey relations operate largely outside the accession framework, except in cases when the proclaimed revitalization of the accession framework as a whole constitutes an incentive structure, as demonstrated by the March 2016 EUTurkey Statement. However, the fragility of the statement as displayed by Turkey's temporary withdrawal from the 'deal' in February 2020 shows that the EU needs to be capable and willing to provide Turkey with attractive and credible incentives to maintain a sustainable cooperation framework based on conditionality. The most prominent existing enforcement structure outside of the accession framework is the EU-Turkey CU, which necessitates Turkey's alignment with the Common Customs Tariff and commercial policy of the EU. However, the asymmetric CU setup is not regarded as fair and appealing by Turkey anymore, which weakens the capacity of the $\mathrm{CU}$ as an enabler of cooperation in the long run as long as the $\mathrm{CU}$ does not undergo modernization.

Naturally, punishments in the event of misbehavior as formulated in Article 7 of the Treaty on European Union do not apply to nonmember states, including Turkey. In multilateral fora, the EU and Turkey are, for instance, bound to the jurisdictions of the European Court of Human Rights in view of the compliance with the European Convention on Human Rights. However, the Court lacks direct enforcement powers as states are not compelled to execute its judgments. Sanction or suspension procedures in NATO are formally not enshrined in the Washington Treaty, ${ }^{4}$ but the gas dispute in the Eastern Mediterranean could potentially become subject to the jurisdiction of the International Court of Justice. In contrast, sanctions, such as those implemented by the EU in response to Turkey's drilling activities (Council of the EU, 2019), cannot be considered as enforcement that facilitates steady

${ }^{4}$ Expelling a member from NATO, however, is legally possible (see Sari, 2019). 
and veritable cooperation structures between the EU and a key third country outside the (currently) futile accession setup, as they are unilaterally imposed without a jointly established compliance framework. Accordingly, under the current circumstances, external incentives granted by the EU within the framework of a jointly negotiated 'transactional' conditionality setup alongside the already existing accession scheme might prove to be the most effective enforcement mechanism to promote EU-Turkey cooperation, mutual trust, and political dialogue in the short run.

\subsection{7 'Identity' (In)Compatibility Between the EU and Turkey}

As a seventh enabler, the sense of a common identity, belonging to the same group with shared norms and beliefs, and the perception of ethnic or cultural commonalities as constructed through communicative practices and political and societal narratives enhances the likelihood of cooperation (Messner et al., 2016). Acknowledged as 'role-specific understandings and expectations about self, [...] identities are the basis of interests' (Wendt, 1992: 397-398). In this context, collective identification with respective communities and institutions and a strong group identity can increase the willingness to both cooperate and prioritize group interests over individual interests; a phenomenon that has been scrutinized in EU studies since the early days of the European integration project (Risse, 2005). Collective identities also bring about emotions such as 'in-group trust' that promote 'in-group cooperation and out-group discrimination' (Mercer, 2005: 97).

In EU-Turkey relations, the discourse on commonalities is simultaneously shaped by a wide array of determinants that range from the norms and values as enshrined in international law and the EU acquis to questions related to a common foreign and security culture and religious-cultural debates (see also Aydın-Düzgit \& Rumelili, Chapter 3; Schimmelfennig, Chapter 6; Tekin, Chapter 7). In the EU, European representations of Turkey's identity are abundant and ambiguous. While conceptions of commonalities rest, for instance, on the presence and integration of citizens of Turkish origin in European societies, strong objections are built upon the alleged incompatibility of Turkey's societal, religious, and cultural foundations with self-proclaimed 'European values' (Lindgaard et al., 2018: 16). The Turkish political leadership draws an ambiguous picture of a potential 'we-identity' (Messner et al., 2016: 55) with the EU, too. Reference to a sense of common belonging is 
part of the rhetorical repertoire still today. To illustrate, Turkish President Recep Tayyip Erdoğan stresses Turkey's determination to gain EU membership and to proceed on 'its way persistently despite those trying to exclude it from the European family' (TRT World, 2019). The lament of being excluded speaks to the in-group-out-group mechanism and is a positive affirmation of a European-Turkish community, even if such references might be employed strategically for the mobilization of domestic sentiments and the pursuit of interests.

One of the most discussed potential dividing lines in the debate over cultural commonalities between the EU and Turkey concerns the relationship between religion and democratic consolidation (Aydın-Düzgit \& Rumelili, Chapter 3). Embracing multi-faith realities in both Turkish and EU societies alongside the possibility of the adherence of Islamic societies to the EU's liberal-democratic norms could be one feature of a common identity in EU-Turkey relations. However, such attempts could encounter two key challenges. First, democratic backsliding in Turkey coupled with trends toward the de-secularization of Turkey's domestic and foreign policymaking (see Kaya, Chapter 14; Torun, Chapter 13) strengthen the perceived qualms about Turkey's 'Europeanness'. Second, the resurgence of populist, nationalist, and illiberal tendencies in various EU member states has sparked discussions over how to conceptualize 'European' democratic values and presented increasing challenges to the cosmopolitan, inclusive contour of European identity. In the present situation, a common identity does not seem to represent a particularly promising starting point to formulate joint interests and facilitate a cooperative EU-Turkey relationship. Given the rich set of joint, deeprooted historical, societal, and political points of reference, on the one hand, and the overarching unfavorable macropolitical settings, on the other, attempts at the construction of a sense of common identity could be above all undertaken through reinforcing intersocietal ties and people-to-people communication.

\subsection{Conclusion: Advancing EU-Turkey Relations aNd EU-Turkey STUdies}

The findings of this volume have revealed how much more intricate, contested, yet relevant EU-Turkey relations have become under the influence of new complexities. This volume is full of evidence of how the preferences of the EU and Turkey were driven, and continue to be driven, 
by an ever-evolving mixture of internal EU and Turkish domestic developments, external shocks, and international developments, as well as by determinants of the bilateral dialogue in the form of the accession process or sectoral cooperation.

Cooperation between the EU and Turkey remains requisite for both parties to manage growing, complex interdependencies across a wide array of issue areas, inter alia, trade, migration, energy, and security. Accordingly, the EU has conveyed that it 'has a strategic interest $[\ldots]$ in the development of a cooperative and mutually beneficial relationship with Turkey' (European Council, 2020: para. 15). However, if cooperation is about adjusting one's own behavior to the other's preferences, we can underscore that the phases and areas of cooperation between the EU and Turkey have substantially decreased throughout the last decade. The last incidence in which organized collective action was undertaken in view of a common challenge was when the EU and Turkey responded to the cross-border implications of the war in Syria with a joint 'deal' on the management of irregular migration flows in March 2016. EUTurkey relations show that enabling conditions are not easy to achieve even with the high potential for reciprocity, which lies at the heart of cooperation. Our analysis has revealed that despite this potential, the EUTurkey relationship lately rests on unfavorable cooperation conditions, since other drivers of cooperative behavior-namely, trust, communication, reputation, fairness, enforcement, and common identity-cannot properly operate in the current setup.

The good news is that cooperation does not necessarily have to become less likely in complex setups like the EU-Turkey relationship. Beyond that, 'the success conditions for cooperation are known to a great extent and $[\ldots]$ can be influenced, which means we can also think about strategies needed to develop or strengthen them' (Messner \& Weinlich, 2016: 14). In the previous sections of this chapter, we have pinpointed possible means and ways to allow for these enablers to facilitate cooperative behavior in EU-Turkey relations. Our analysis and the findings in the various contributions of this volume suggest that sectoral, transactional interactions based on the principle of direct reciprocity bear the potential to reverse the vicious circle in EU-Turkey relations, enabling a favorable working environment at the operational level. Ad hoc horizontal, sectordriven transgovernmental networking (Lavenex, 2008, 2014) with the involvement of actors at multiple levels, including local administrators, technocrats, regulatory agencies, and a diverse set of non-state actors, 
might facilitate issue-specific de-politicization in the EU-Turkey relationship and encourage trust-building between the two parties in the short run (see also Turhan \& Yildiz, forthcoming).

At the same time, the findings of the volume reveal that the convergence of interests does not necessarily safeguard the longevity of collective action toward reaching common goals. A truly cooperative relationship between the EU and Turkey, therefore, implies a long-term, normative orientation and stable cooperation with continuous communication in order to decrease the likelihood of misinterpretations and, accordingly, perceptions of unfairness and the development of disrepute. In this way, learning and socialization processes and rule-based systematized policy coordination may (re)emerge. Thus, the future trajectory of EUTurkey relations requires a normative, 'institutionalized alternative path' (Turhan \& Wessels, Chapter 8) beyond the formally frozen accession process in order to negate the phases of estrangement and conflictual relations and promote the longevity of the periods epitomized by a cooperative relationship. In this vein, the concept of external differentiated integration that concerns the extraterritorial, partial extension of the EU acquis through 'alternative forms of integration below the threshold of membership' (Lavenex, 2011: 373) constitutes a promising framework 'for conceptualizing the different forms of Turkey's integration and association with the EU' (Tekin, Chapter 7; see also Turhan, 2017; Müftüler-Baç, 2017). Should future developments allow for a reinvigorated discussion of the EU-Turkey relationship as a realistic case of EU enlargement, the preferences and influence of individual member states such as Germany (Reiners \& Tekin, 2020; Turhan, 2016) and of EU institutions will continue to play a central role in this context as will EU-Turkey interactions in key policy areas.

Taking into consideration the findings - and thematic boundaries-of this volume as well as the growing evolution of the EU-Turkey relationship outside the accession process, we propose three avenues for future research. First, overcoming the unlikelihood of a fully-fledged revitalization of Turkey's EU accession talks accompanied by the indispensability of policy coordination necessitates further studies on the explanatory value of the concept of external differentiated integration for EU-Turkey relations. More specifically, there is significant gap in the literature on the causes and drivers of variations in Turkey's external differentiated integration with the EU. Beyond that, the different modes of interactions between the EU and Turkey through which policy transfer is 
pursued outside the accession framework and the effects of sector-specific, functional integration on domestic normative transformation in Turkey require deeper analysis.

Second, micro- and meso-level analyses of EU-Turkey relations still remain relatively understudied sub-fields. How has the recent deterioration in political relations affected the relationship at the administrative, more technical level (Bürgin, Chapter 9)? What channels of communication and socialization exist between the EU institutions and Turkey's opposition parties or civil society? How do mutual identity representations change in response to key contemporary developments in the EU and Turkey (Aydın-Düzgit \& Rumelili, Chapter 3)?

Finally, without a dynamic accession track, the EU's relations with Turkey would resemble the Union's relations with other emerging (middle-)powers and become increasingly concerned with the debates on important overarching questions of inter- and transnational cooperation as well as the quest for effective multilateralism in times of global power shifts. This emerging setup necessitates attempts to go beyond the theories of European integration; in other words, we need to expand theoretical and analytical explorations that further scrutinize the explanatory value of mainstream and up-and-coming IR theories and governance studies for EU-Turkey relations. In this way, it would be possible to advance EU-Turkey studies as a field of analysis at the intersection of EU (integration) studies, IR, and (global) governance studies.

The stalemate in Turkey's EU accession process does not dilute the relevance of EU-Turkey relations. As seen throughout this volume, even a comprehensive analysis of contemporary EU-Turkey relations through the lenses of theories and concepts, institutions, and policies cannot fully grasp the ever-evolving complexities and components of this unique relationship. Rather, such an extensive look at the relationship through these perspectives opens new avenues for future research and innovative forms of cooperation.

\section{REFERENCES}

Akman, M. S., \& Çekin, S. E. (2021). The EU as an anchor for Turkey's macroeconomic and trade policy. Chapter 12 , in this volume.

Alpan, B. (2021). Europeanization and Turkey's EU accession: Three domains, four periods. Chapter 5 , in this volume. 
Aydın-Düzgit, S., \& Rumelili, B. (2021). Constructivist approaches to EUTurkey relations. Chapter 3 , in this volume.

Barigazzi, J. (2016, May 30). Threats, insults and praise: 9 Erdoğan quotes on Europe. Politico. https://www.politico.eu/article/threats-insults-and-pra ise-9-recep-tayyip-erdogan-quotes-on-europe/. Accessed 31 Aug 2020.

Barilleaux, R. J. (1985). The president, 'intermestic' issues, and the risks of policy leadership. Presidential Studies Quarterly, 15(4), 754-767.

Bürgin, A. (2021). The European Commission's role in EU-Turkey relations. Chapter 9 , in this volume.

Council of the European Union. (2019, November 8). Council decision concerning restrictive measures in view of Turkey's unauthorised drilling activities in the Eastern Mediterranean. 13262/19. Brussels.

Economist Intelligence Unit (EIU). (2020, July). Country report Turkey.

European Commission. (2018, June 14). EU budget: Making the EU fit for its role as strong global actor. Press release. IP/18/4086. Brussels.

European Commission. (2019a, December 11). The European Green Deal. $\operatorname{COM}(2019) 640$ final. Brussels.

European Commission. (2019b, December 11). EU as a global partner: The European Green Deal. Factsheet. FS/19/6721. Brussels.

European Commission. (2019c). Standard Eurobarometer 92. Autumn. Brussels. European Commission. (2020a, October 6). Turkey 2020 report. SWD(2020) 355 final. Brussels.

European Commission. (2020b). State of the Union address 2020. https:// ec.europa.eu/info/sites/info/files/soteu_2020_multilingual.pdf. Accessed 16 Sept 2020.

European Council. (2020, 2 October). Special meeting of the European Council ( 1 and 2 October 2020)-Conclusions. EUCO 13/20. Brussels.

Euronews. (2015, May 28). 'Frustration, mistrust and disappointment'Turkey's strained ties with Europe. https://www.euronews.com/2015/ $05 / 28 /$ frustration-mistrust-and-disappointment-turkey-s-strained-ties-witheurope. Accessed 2 Sep 2020.

Fearon, J. D. (1998). Bargaining, enforcement, and international cooperation. International Organization, 52(2), 269-305.

Feliu, L., \& Serra, F. (2015). The European Union as a 'normative power' and the normative voice of the European Parliament. In S. Stavridis \& D. Irrera (Eds.), The European Parliament and its international relations (pp. 17-34). London: Routledge.

Forschungsgruppe Wahlen. (2018, February 23). Politbarometer Februar II 2018. CDU/CSU im Aufwind-SPD auf neuem Rekordtief-Deutliche Mehrheit erwartet Zustandekommen der Großen Koalition. https://www. forschungsgruppe.de/Umfragen/Politbarometer/Archiv/Politbarometer 2018/Februar_II_2018/\#. Accessed 27 Nov 2020. 
Hauge, H.-L., Özbey, E. E., Eralp, A., \& Wessels, W. (2019). Narratives of a contested relationship: Unravelling the debates in the EU and Turkey. FEUTURE Online Paper No. 28, February. https://feuture.uni-koeln.de/ sites/feuture/user_upload/Online_Paper_No_28.pdf. Accessed 2 Sep 2020.

Icoz, G., \& Martin, N. (2021). Historical institutionalism and EU-Turkey relations: path dependence and critical junctures in the accession process. Chapter 4 , in this volume.

Kaeding, M., \& Schenuit, F. (2021). The European Parliament's perspective on EU-Turkey relations. Chapter 10, in this volume.

Kapstein, E. B. (2008). Fairness considerations in world politics: Lessons from international trade negotiations. Political Science Quarterly, 123(2), 229-245.

Kaya, A. (2021). Europeanization and de-Europeanization of Turkish asylum and migration policies. Chapter 14, in this volume.

Keohane, R. O. (1984). After hegemony: Cooperation and discord in the world political economy. Princeton: Princeton University Press.

Keohane, R. O. (1986). Reciprocity in international relations. International Organization, 40(1), 1-27.

Kokaz, N. (2005). Theorizing international fairness. Metaphilosophy, 36(1/2), 68-92.

Kydd, A. H. (2007). Trust and mistrust in international relations. Princeton: Princeton University Press.

Lavenex, S. (2008). A governance perspective on the European neighbourhood policy: Integration beyond conditionality? Journal of European Public Policy, 15(6), 938-955.

Lavenex, S. (2011). Concentric circles of flexible 'EUropean' integration: A typology of EU external governance relations. Comparative European Politics, $9(3), 372-393$.

Lavenex, S. (2014). The power of functionalist extension: How EU rules travel. Journal of European Public Policy, 21(6), 885-903.

Lavenex, S., \& Wichmann, N. (2009). The external governance of EU internal security. Journal of European Integration, 31(1), 83-102.

Lindgaard, J., Wessel, A. U., \& Stokholm Banke, C. F. (2018, April). Turkey in European identity politics: Key drivers and future scenarios (FEUTURE Online Paper No. 19). https://feuture.uni-koeln.de/sites/feuture/user_upload/Onl ine_Paper_No_19_D7.2.pdf. Accessed 28 Aug 2020.

Lippert, B. (2021). Turkey as a special and (almost) dead case of EU enlargement policy. Chapter 11 , in this volume.

Mercer, J. (2005). Rationality and psychology in international politics. International Organization, 59(1), 77-106.

Messner, D., Gurain, A., \& Haun, D. (2016). The behavioural dimensions of cooperation. In D. Messner \& S. Weinlich (Eds.), Global cooperation and the 
buman factor in international relations (pp. 47-65). London and New York: Routledge.

Messner, D., \& Weinlich, S. (2016). The evolution of human cooperation: Lessons learned for the future of global governance. In D. Messner \& S. Weinlich (Eds.), Global cooperation and the human factor in international relations (pp. 3-46). London and New York: Routledge.

Milner, H. (1992). International theories of cooperation among nations: Strengths and weaknesses. World Politics, 44(3), 466-496.

Müftüler-Baç, M. (2017). Turkey's future with the European Union: An alternative model of differentiated integration. Turkish Studies, 18(3), 416-438.

Park, B. (2007). The EU and Turkey. In D. Brown \& A. Shepherd (Eds.), The security dimensions of EU enlargement: Wider Europe, weaker Europe? (pp. 157-173). Manchester: Manchester University Press.

Rathbun, B. C. (2011). The 'magnificent fraud': Trust, international cooperation, and the hidden domestic politics of American multilateralism after World War II. International Studies Quarterly, 55(1), 1-21.

Reiners, W., \& Tekin, F. (2020). Taking refuge in leadership? Facilitators and constraints of Germany's influence in EU migration policy and EU-Turkey affairs during the refugee crisis (2015-2016). German Politics, 29(1), 115130 .

Risse, T. (2005). Neofunctionalism, European identity, and the puzzles of European integration. Journal of European Public Policy, 12(2), 291-309.

Rosamond, B. (2000). Theories of European integration. New York: Palgrave Macmillan.

Sari, A. (2019, October 15). Can Turkey be expelled from NATO? It's legally possible, whether or not politically prudent. Just Security. https://www. justsecurity.org/66574/can-turkey-be-expelled-from-nato/. Accessed 11 Apr 2021.

Sartori, N. (2021). EU-Turkey energy dialogue: Moving beyond the accession negotiations framework. Chapter 15, in this volume.

Schäfer, M., Haun, D. B. M., \& Tomasello, M. (2015). Fair is not fair everywhere. Psychological Science, 26(8), 1252-1260.

Schimmelfennig, F. (2021). Rhetorical entrapment in EU-Turkey relations. Chapter 6, in this volume.

Schimmelfennig, F., \& Sedelmeier, U. (2004). Governance by conditionality: EU rule transfer to the candidate countries of Central and Eastern Europe. Journal of European Public Policy, 11(4), 661-679.

Şenyuva, Ö. (2018, October). Turkish public opinion and the EU membership: Between support and mistrust (FEUTURE Online Paper No. 26). http://www.feuture.uni-koeln.de/sites/feuture/user_upload/Onl ine_Paper_No_26_final.pdf. Accessed 2 Sep 2020. 
Snidal, D. (1985, December). Coordination versus prisoners' dilemma: Implications for international cooperation and regimes. The American Political Science Review, 79(4), 923-942.

Tekin, F. (2021). Differentiated integration: An alternative conceptualization of EU-Turkey relations. Chapter 7 , in this volume.

Torun, Z. (2021). From convergence to divergence: The compatibility of Turkish and EU foreign policy. Chapter 13 , in this volume.

TRT World. (2019, May 9). Turkey working insistently for full EU membership_Erdogan. https://www.trtworld.com/turkey/turkey-workinginsistently-for-full-eu-membership-erdogan-26519. Accessed 28 Aug 2020.

Tsarouhas, D. (2021). Neoliberalism, liberal intergovernmentalism and EUTurkey relations. Chapter 2 , in this volume.

Turhan, E. (2012). The European Council decisions related to Turkey's accession to the EU: Interests vs. norms. Baden-Baden: Nomos.

Turhan, E. (2016). Turkey's EU accession process: Do member states matter? Journal of Contemporary European Studies, 24(4), 463-477.

Turhan, E. (2017, July 3). Thinking out of the accession box: The potential and limitations of internal and external differentiated integration between Turkey and the EU (CIFE Policy Paper No. 58). https://www.cife.eu/Ressou rces/FCK/files/publications/policy\%20paper/CIFE_Policy_Paper_58_Thi nking_out_of_The_Accession_Box_EU_Turkey_Ebru_Turhan_2017_1.pdf. Accessed 28 Nov 2020.

Turhan, E., \& Reiners, W. (2021). Unpacking the new complexities of EUTurkey relations: Merging theories, institutions, and policies. Chapter 1 , in this volume.

Turhan, E., \& Wessels, W. (2021). The European Council as a key driver of EU-Turkey relations: Central functions, internal dynamics and evolving preferences. Chapter 8 , in this volume.

Turhan, E., \& Yildiz, A. (forthcoming). Turkey's external differentiated integration with the EU in the field of migration governance: The case of border management. In B. Leruth, S. Gänzle, \& J. Trondal (Eds.), The Routledge bandbook of differentiation in the European Union. London: Routledge.

Türkiye Cumhuriyeti Cumhurbaşkanlığı İletişim Başkanlığı. (2019). Cumhurbaşkanı Erdoğan: "Güvenlik olmadan barış olmaz, barış olmadan kalkınma olmaz". https://www.iletisim.gov.tr/turkce/haberler/detay/cum hurbaskani-erdogan-guvenlik-olmadan-baris-olmaz-baris-olmadan-kalkinmaolmaz. Accessed 10 Nov 2020.

Wendt, A. (1992). Anarchy is what states make of it: The social construction of power politics. International Organization, 46(2), 391-425.

Wiener, A., \& Diez, T. (2009). European integration theory (2nd ed.). Oxford: Oxford University Press. 
Zeit Online. (2020, August 29). Türkei warnt vor Kriegsgrund im Gasstreit mit Griechenland. https://www.zeit.de/politik/ausland/2020-08/grenzverl auf-mittelmeer-tuerkei-griechenland-gasstreit-kriegsgrund. Accessed 30 Aug 2020.

Zürcher, E. J. (2004). Turkey: A modern history. London and New York: I.B. Tauris.

Wulf Reiners is senior researcher and head of the 'Managing Global Governance' (MGG) program of the German Development Institute / Deutsches Institut für Entwicklungspolitik (DIE). He is also the coordinator of the Horizon 2020 project PRODIGEES (2020-2023) on digitalization and sustainable development in Europe and emerging economies. Before joining DIE, he was assistant professor at the Turkish-German University in Istanbul, academic coordinator of the Jean Monnet Module 'INSITER-Inside the Turkey-EU Relations' (20162017), researcher, lecturer, and project manager at the University of Cologne, and Marie Curie Visiting Researcher at the University of Pittsburgh. He obtained his Ph.D. in Political Science from the University of Cologne. His current research interests include global governance, emerging economies, EU-Turkey relations, EU external action, sustainable development, and digitalization.

Ebru Turhan is assistant professor at the Department of Political Science and International Relations, Turkish-German University (TDU), Istanbul. She also serves as a senior research fellow at the Institute for European Politics (IEP) in Berlin. Turhan was the academic coordinator of the Jean Monnet Module 'INSITER-Inside the Turkey-EU Relations' (2016-2019), co-financed by the European Commission. Before joining the Turkish-German University in September 2015, she was a Mercator-IPC fellow and post-doctoral researcher at the Istanbul Policy Center (IPC) of the Sabancı University. Her current research interests include EU-Turkey relations, external differentiated integration, EU enlargement policy, German-Turkish relations, and decolonizing and degendering knowledge. Turhan holds an MA in Contemporary European Studies from the University of Bath and a Ph.D. in Political Science from the University of Cologne. 
Open Access This chapter is licensed under the terms of the Creative Commons Attribution 4.0 International License (http://creativecommons.org/licenses/ by $/ 4.0 /$ ), which permits use, sharing, adaptation, distribution and reproduction in any medium or format, as long as you give appropriate credit to the original author(s) and the source, provide a link to the Creative Commons license and indicate if changes were made.

The images or other third party material in this chapter are included in the chapter's Creative Commons license, unless indicated otherwise in a credit line to the material. If material is not included in the chapter's Creative Commons license and your intended use is not permitted by statutory regulation or exceeds the permitted use, you will need to obtain permission directly from the copyright holder.

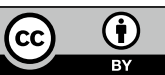

